\section{教育機関 (大学) めぐり (3)}

\section{東京芸術大学美術学部 工芸科陶芸講座}

東京芸術大学美術学部工芸科陶芸講座は昭和 37 年 9 月に開讙され，丁度，满 1 年をむか学たととろである。

芸術大学がまだ美術学校であった当時から，日本の工 芸教育の学校でありながら, 陶芸教育の場がないととの 片手落を言初る人々は多かったが，東京という地理的 条件のためか，または予算のためか，なかなか開設され る段階にならなかった様子で, 敗戦数年後, 新制大学の 芸術大学々なっても，正規の講座としては設置されず， 学生達の希望によって学生自治会のクラブ活動の一環と して陶磁研究会が発足し，運動場の一隅の小さな仕事場 飞数台の動力口クロと倒炤式の小さな試駼用石㞸窝が， 現主任教授の加藤土師萠先生の奉仕的努力によって造ら れ, 数年の閤, 学生達の自主的研究の場として続けられ て来た。

この陶磁研究会が母体となり, 現学長の小塚新一郎先 生の努力と加藤教授の熱意により, 工芸科校舎の改築と 合まって昨年 9 月設備も新たに新講座として発足した。

新請座設置にあたっては, 東京工大窯業科等よりの陰 からの援助もあったように聞いている．何分にも文部省 よりの予算のわくが少なく，新しい機械類の購入等はは とんぞ加藤教授の個人的努力で寄付を集められてまがな

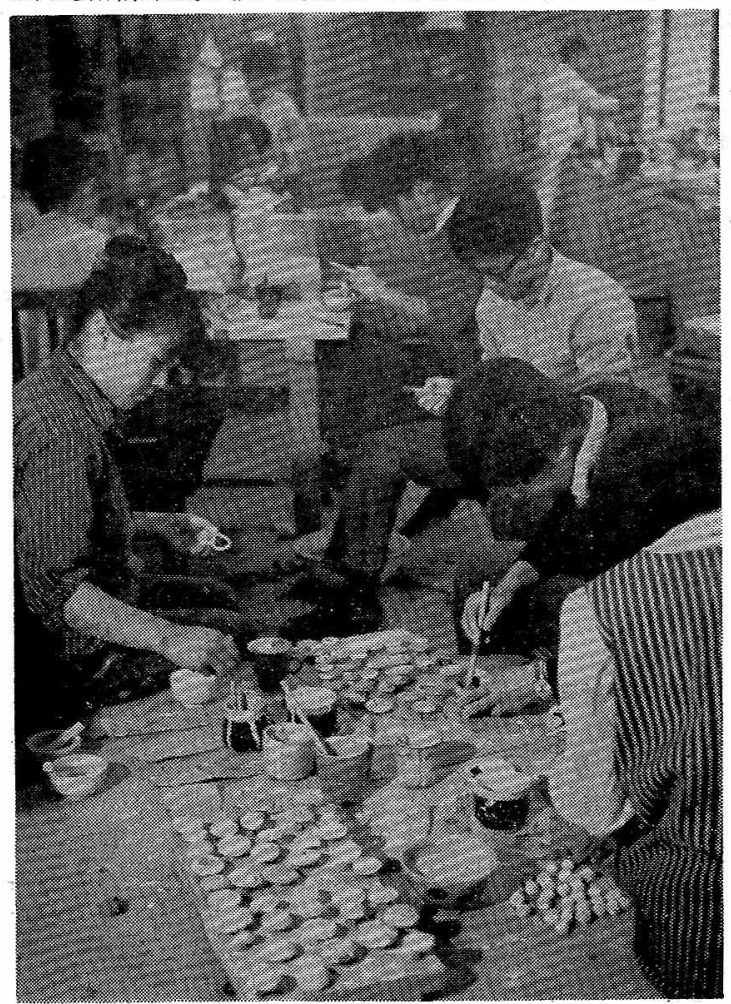

実習 教 窒
われたるので，教授の実践活動力なくしては今日の本講 座の設備の状態は考光られない。

機械設備としてはスタンパー，横式土練機，泥将摬拌 機, 泥装圧㩁用ポンプ,フィルタープレス等の坏土調整

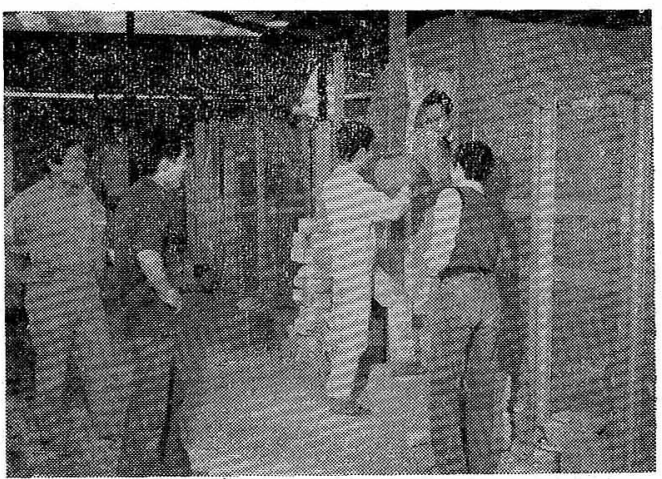

空

場

備にポットミル，成形用としては動力付緩急ロクロ（小 西式 22 台, 新保式 3 台) 計 25 台, 石膏型原型口ク口 3 台, 成形用型口ク口 3 台. 䇺は倒炤式重油突, 石炭

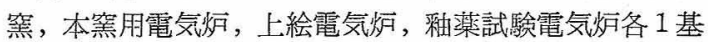
ずつで, 不完全ながらも，現在日本で工芸陶磁教育の設 供をすつ学校としては，恐らく一番充実したものではは いかと思っている。

アメリカ, 北欧等の学校加ら見に来引れた人々の話に よっても,との程度の設備在持つ学校は少ないというと とである。

教授わよび研究空の陣営は加藤土師萠教授を主任と し, 昨年開講之共に市立京都美大陶磁器科より転席して 来た藤本能道を助教授に, 陶磁研究会当時より学生のぬ んぞうを見て来た浅野陽君を專任講師とし, 助手 1 名, 副手 2 各を㧍意, 陶磁史を小山富士夫先生, 陶磁原料学 を東京工大の素木洋一先生，石膏型制作法を前飞大倉陶 園におられた藤崎秀雄氏に講師としてお願いしているの が現状である。

日本ほど陶磁の美を愛好し, 高く評価する国はないと よく言われるが，それでけに日本の陶芸界ほど複雑な椂 相を呈している国もないのではないかと思われる。

茶道・華道の普及と, 日本特有の食生活の様式加ら生 まれて来た特種な陶磁に対する観賞態度, それらのム一 ドと結びついて起った東洋古陶䣲に対する骨董趣味, 個 性の表現と䚇賞のための一品制作陶磁，高価な一品制作 陶磁と大量生産品との間隙をうめようとする手工的小量 産の陶磁，大量機械生産の陶磁，また，日本で造られな がら日本人の生活様式とはまったくかけ離れた特種な貿 易用の陶磁, 等々。

まったく複雑な分野に別れなんとなく別個の立場 で, 別々の物の見方で, まるで無縁な奾界のように造ら れ，使用，観賞されている現状を考光る時に技術や美の 間題以前にての状熊をはっきりとつかみ，何を採り，何 を捨てて，上りよき明日の陶磁工芸を造り得る人々を育 てて行てうとするととは，ほんとうにむつ玑いてとだ と痛感している。

(藤本，能道) 